\title{
Heterotrophic microbial activities and nutritional status of microbial communities in tropical marsh sediments of different salinities: the effects of phosphorus addition and plant species
}

\author{
Barbora Pivničková • Eliška Rejmánková • \\ Jenise M. Snyder • Hana Šantrůčková
}

Received: 31 October 2009 / Accepted: 13 May 2010/Published online: 4 June 2010

C The Author(s) 2010. This article is published with open access at Springerlink.com

\begin{abstract}
Oligotrophic, phosphorus (P) limited herbaceous wetlands of northern Belize are being impacted by $\mathrm{P}$ loading from fertilizer runoff. $\mathrm{P}$ enrichment causes a shift in autotroph communities from a microphyte (cyanobacterial mats, CBM) to macrophyte (Eleocharis spp., Typha domingensis) dominated system. To document potential effects of $\mathrm{P}$, salinity, and macrophyte species on the heterotrophic microbial community nutritional status (represented especially by specific phospholipids fatty acids and specific respiration rate), biomass and activities, we took soil samples from established $\mathrm{P}$ enrichment plots in replicated marshes of two salinity levels. P addition increased microbial biomass carbon (C), nitrogen $(\mathrm{N})$ and $\mathrm{P}$, as well as soil nutrient transformation rates (nitrogenase activity, $\mathrm{N}$ mineralization and immobilization, methanogenesis). The effect of plant species (Eleocharis vs Typha sites) was gener-
\end{abstract}

Responsible Editor: Liz Shaw.

B. Pivničková $(\bowtie) \cdot H$. Šantrůčková

Faculty of Science, University of South Bohemia,

Branišovská 31,

České Budějovice 370 05, Czech Republic

e-mail: bara.pivnickova@seznam.cz

E. Rejmánková • J. M. Snyder

Department of Environmental Science and Policy,

University of California Davis,

One Shields Ave.,

Davis, CA 95616, USA ally lower than the effect of $\mathrm{P}$ addition (CBM vs Eleocharis sites) and was most evident at the low salinity sites, where Eleocharis dominated plots had enhanced nitrogenase activity and P microbial immobilization. Salinity reduced the overall rates of microbial processes; it also weakened the positive effect of both $\mathrm{P}$ addition and plant species on microbial activities. Lastly, the amount of $\mathrm{N}$ stored in microbial cells, likely in form of osmoprotective compounds, was enhanced by salinity.

Keywords Phosphorus loading - Eleocharis - Typha . Salinity $\cdot$ Microbial biomass $\cdot$ Nitrogen

$\begin{array}{ll}\text { Abbreviations } \\ \text { CBM } & \text { Cyanobacterial mats } \\ \text { NA } & \text { Nitrogenase activity } \\ \text { DEA } & \text { Denitrification enzyme activity } \\ \text { PLFA }_{\text {tot }} & \text { Amount of phospholipid fatty acids } \\ \text { TBFA } & \text { Terminally branched fatty acid } \\ \text { SRB } & \text { Sulfate reducing bacteria } \\ \text { MBC } & \text { Microbial biomass carbon } \\ \text { MBN } & \text { Microbial biomass nitrogen } \\ \text { MBP } & \text { Microbial biomass phoshorus } \\ \text { P }_{\text {ox }} & \text { Oxalate extractable sediment P } \\ \text { C avail } & \text { Available carbon } \\ \text { QCO2 } & \text { Specific respiration rate } \\ \text { MUFA/ } & \text { Monounsaturated/saturated fatty acids } \\ \text { STFA } & \text { ratio }\end{array}$




\section{Introduction}

In aquatic and wetland systems, microorganisms are the most abundant and important biological component involved in organic matter turnover (Pomeroy and Wiegert 1981). Organic matter is used by microbes as a growth substrate and nutrient supply; it is the location, quantity, and quality of organic matter that determine microbial abundance and production (Cunha et al. 2000; Boschker et al. 1999).

In marsh sediments, microbial production is generally high and strongly influenced by organic matter released from primary producers' exudates and/or decomposing litter (Moriarty and Pollard 1981). Carbon from the organic matter is assimilated into the microbial biomass or rapidly transformed to $\mathrm{CO}_{2}$ (Créach et al. 1999). The size, composition, and activity of the heterotrophic microbial pool are all a reflection of the dominant plant species' partitioning of resources and growth (Semenov et al. 1999). Among the possible mechanisms, plants regulate nutrient availability by competing with microorganisms for nutrient resources and control sediment aeration by consuming or releasing oxygen to the rhizosphere.

Plant production is determined by a wide range of environmental factors, among which, nutrient availability often plays a major role, especially in oligotrophic wetlands. While macrophyte community changes following nutrient loading have been reported for various types of wetlands (Childers et al. 2003; Wolin and Mackeigan 2005), it is not clear how the changes in macrophytes, in turn, affect the sediment microbial communities (Ravit et al. 2006; Francoeur et al. 2006). The effect of macrophytes on heterotrophic microbial activity, as well as on rhizospheric bacterial composition may be species specific (Bagwell et al. 2002; Burke et al. 2002). The presence of plant species with distinct growth patterns and resource allocation can lead to differences in the proportion of modified bulk soil, and, thus, result in different populations and/or degrees of soil microbial activities (Semenov et al. 1999).

Wetlands can vary widely in salinity level, with high salinity posing a potential stress to plants as well as microbial growth. In saline environments, bacteria have to cope with ionic stress, which is balanced by intracellular osmoprotective compounds, many of which are sugars (Welsh and Herbert 1999) or contain
N (amino acids and their derivatives; Csonka 1989; Galinski and Trüper 1994). Even under moderate increases in salinity, bacteria may modify the chemical composition of their cell membranes, synthesizing and altering the patterns of proteins, lipids, fatty acids and polysaccharides (Zahran 1997).

This study focuses on a wetland site in northern Belize that is well suited to assess the impact of different plant species on sediment microbial communities. The site includes marshes of a wide range of salinities with a well established system of nutrient enriched plots, which are dominated by only a few macrophyte species (Rejmánková et al. 2008). Under natural un-impacted conditions, all of these wetlands are dominated by benthic cyanobacterial mats with scattered macrophytes, mainly Eleocharis cellulosa and E. interstincta, and are strongly $\mathrm{P}$ limited. The region is experiencing increasing nutrient inputs from fertilizer runoff due to the expansion of sugar cane cultivation and its impact, specifically the expansion of Typha domingensis, has been documented in some of the marshes (Johnson and Rejmánková 2005). In 2001, we initiated a long term manipulative experiment using these wetlands as a model system, to obtain a mechanistic explanation for an ecosystem level response to increased nutrient input across a salinity gradient. We have already confirmed that $\mathrm{P}$ addition leads to almost total elimination of cyanobacterial mats due to the expansion of Eleocharis cellulosa, and, eventually, the replacement of Eleocharis by Typha domingensis (Rejmánková et al. 2008).

Both Eleocharis and Typha are rhizomatous perennials, but while Eleocharis is a good example of a stress tolerator adapted to P limitation stress, Typha behaves as a competitor (sensu Grime 2001) and is able to outcompete Eleocharis once the P-limitation has been removed (Macek and Rejmánková 2007). We expected that due to their different biomass production, nutrient uptake, and resorption (Rejmánková 2005), these two macrophytes will provide organic material of contrasting amounts and quality to the sediments and, consequently, they will differentially impact the microbial activities in the respective sediments.

The aim of this paper is to document how microbial biomass and activities (nitrogen and carbon mineralization, denitrification enzyme activity and nitrogenase activity) in wetland sediments are impact- 
ed by the addition of a limiting nutrient $(\mathrm{P})$ and the accompanied changes in macrophyte species and production. Based on previous results on macrophyte growth and plant tissue composition in $\mathrm{P}$ enriched wetlands, we expect that the functioning of sediment microflora will be positively impacted by a greater input of organic carbon through plant litter and root exudates and by more favorable $\mathrm{C} / \mathrm{P}$ ratio of the plant litter (Fig. 1). Using wetlands of two contrasting salinity levels allows us to interpret the data in the salinity context.

We hypothesize that:

1. The nutrient content ( $\mathrm{N}$ and $\mathrm{P}$ stoichiometry) in microbial biomass will be enhanced either directly by the removal of $\mathrm{P}$ limitation, or indirectly by increased available $\mathrm{C}$ from macrophyte exudation and a litter.

2. Plant species will differ in quality $(C, N, P$ favorable stoichiometric ratio) and quantity of a litter thus affecting microbial biomass and activity.

3. An enhanced microbial $\mathrm{N}$ demand will be reflected in faster $\mathrm{N}$ transformations.

4. The rate and direction of the changes in microbial activities and biomass will be salinity dependent.

\section{Materials and methods}

Study site

Our study area is located in the lowlands of northern Belize, Central America within a $50 \mathrm{~km}$ radius of $18^{\circ} 9^{\prime}$ $58^{\prime \prime} \mathrm{N}$ and $88^{\circ} 31^{\prime} 28^{\prime \prime}$. A detailed description has been provided elsewhere (Černá et al. 2009; Rejmánková et al 2008). Briefly, the limestone geology and occasional intrusion of seawater result in diverse range of water conductivities $(0.2-7 \mathrm{mS})$ with large differences in sulfate, bicarbonate and chloride. The climate of the region is tropical wet-dry. The majority of wetlands in the study area remain flooded or water saturated year round, although the total flooded area may vary as water levels rise and fall.

The main primary producers in these systems are several species of emergent macrophytes (Eleocharis cellulosa, E. interstincta, Cladium jamaicense and Typha domingensis) and species rich communities of microphytes represented mostly by cyanobacteria (Rejmánková et al. 2004). Both the macro- and microphytes in these wetlands are generally P limited (Rejmánková 2001; Rejmánková and Komárková 2000). No nitrogen limitation has been detected in any of the reported studies.

Treatment plot history

Fifteen marshes of diverse salinities, all dominated by sparse macrophytes (Eleocharis spp.) and cyanobacterial mats (CBM), have been studied as a part of a project aimed at assessing the ecosystem response to nutrient addition along a salinity gradient (Rejmánková et al. 2008). In August of 2001 , four $10 \times 10 \mathrm{~m}$ plots were established in each marsh, with one representing a control, and the remaining three receiving N, P and N \& $P$ additions in August 2001, August 2002 and March 2005. $\mathrm{N}$ was added as ammonium nitrate and $\mathrm{P}$ as triple super phosphate in amounts corresponding to 20 and $10 \mathrm{~g} \mathrm{~m}^{-2} \mathrm{y}^{-1}$, respectively. In March 2003, one individual of Typha domingensis was planted in each plot. While the Typha plant did not survive in the majority of controls and $\mathrm{N}$ addition plots, it grew and spread vigorously in the $\mathrm{P}$ enriched plots, and outcompeted Eleocharis. In January of 2005 to current, the $\mathrm{P}$ addition plots in six of the 15 marshes have been manipulated and maintained to be half dominated by Eleocharis and half dominated by Typha (Fig. 2). In March 2007, four of these six marshes, two from the low and two from the high salinity categories, were sampled to dually measure the impact of $\mathrm{P}$ addition and macrophyte dominance on the microbial activities and community composition. For the general characteristics of these marshes see Table 1.

\section{Soil sampling}

During the time of sampling, all plots were flooded and the water depth ranged from $25 \mathrm{~cm}$ to $70 \mathrm{~cm}$. At each marsh, samples were collected from (1) control plots with sparse growth of Eleocharis (low-phosphorus Eleocharis, LP/E), (2) P-addition plots dominated by Eleocharis cellulosa (high-phosphorus Eleocharis, HP/E) and (3) P-addition plots dominated with Typha domingensis (high-phosphorus Typha, $\mathrm{HP} / \mathrm{T}$ ); for experimental design and sampling strategy see Fig. 2. Recently deposited, readily distinguishable plant detritus on the soil surface was gently removed before sampling. Eight randomly located sediment samples were collected with a $5.5 \mathrm{~cm}$ diameter sharp 


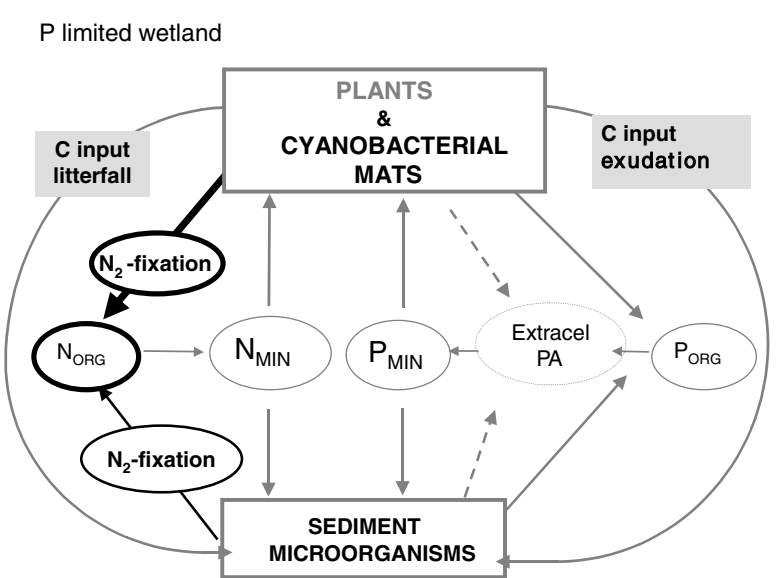

Fig. 1 Conceptual diagram of microbial processes in (a) $\mathrm{P}$ limited and (b) P loaded wetlands. $\mathrm{P}$ enhances the role of sediment microorganisms (indicated by extended arrows) in nutrient transformation processes due to an increase of organic

edge PVC corer to a depth of approximately $30 \mathrm{~cm}$. The upper section $(1-10 \mathrm{~cm})$ representing mostly the rhizosphere, was used for the analyses. Samples were placed in ziplock bags and transported on ice. Large plant debris, roots and shells were removed and samples were homogenized. Nitrogenase activity and $\mathrm{N}-\mathrm{NH}_{4}$ and $\mathrm{N}-\mathrm{NO}_{3}$ contents in sediment were measured immediately. Samples for the remaining analyses were divided into two parts. One part was stored in sealed bags for a maximum of 1 month at $4^{\circ} \mathrm{C}$ and the other was oven dried at $105^{\circ} \mathrm{C}$ to a constant weight for determination of the gravimetric water content and elemental composition $(\mathrm{C}, \mathrm{N}$, reactive $\mathrm{P}$ ) of the soil. All the subsequent analyses were conducted in triplicate.

Plant biomass and tissue analyses

For Eleocharis, plant height was measured and shoots were counted in ten randomly selected $20 \times 20 \mathrm{~cm}$

\section{LOW SALINITY}
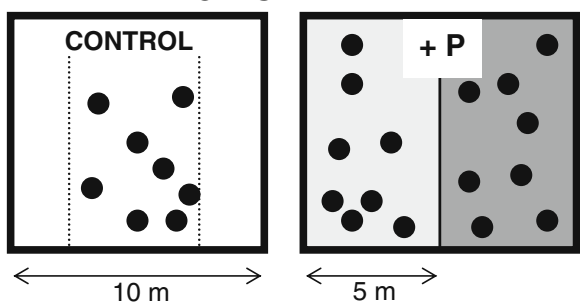

Fig. 2 Schematics of the experimental design and sampling strategy. Eight soil cores were randomly collected (black dots) from control plots (white) and P-enriched plots dominated by
P loaded wetland

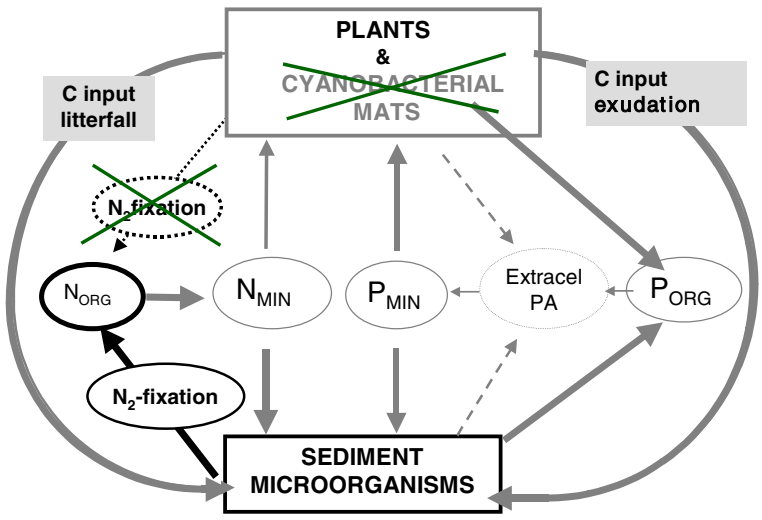

C input through plant litter and root exudates and by the elimination of cyanobacterial mats. Extracel PA = extracelular phosphatase activity

subplots in each plot. Ten mature stems from each plot were collected and their length measured before drying $\left(80^{\circ} \mathrm{C}\right)$ and weighing to calculate the specific stem weight $\left(\mathrm{g} \mathrm{cm}^{-1}\right)$. The biomass was expressed as a product of the average number of stems $\times$ average height $\times$ specific stem weight. The same dried plant material was ground on a Wiley mill and used for nutrient analysis. To assess the nutrient content of litter, representative samples of recently senescent leaf/stem tissue were collected, dried, ground and analyzed. For Typha, the number of leaves and average leaf length were measured on 8-10 randomly selected individuals in each plot and the number of individuals was counted in 8-10 random square $\mathrm{m}$. The biomass was expressed using the correlation between total leaf length and dry mass. The annual primary production was expressed as biomass multiplied by the turnover rate (2.6 and 3 for Eleocharis and Typha, respectively; calculated from plant longevity, see Rejmánková et al. 2008). The annual

HIGH SALINITY

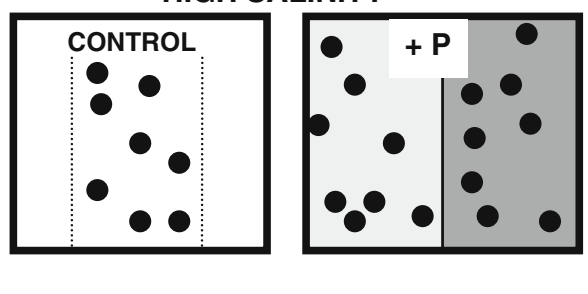

Eleocharis (light gray) and Typha (dark gray). To avoid the discrepancy in plot size; only $5 \times 10 \mathrm{~m}$ area (indicated by dotted line) was sampled in controls 
Table 1 Characteristics of the selected marshes from August 2001, before the beginning of the nutrient addition experiment. Values represent means of four $10 \times$ $10 \mathrm{~m}$ plots in each marsh for water conductivity, and soil total P and N. Standard deviations are given within the parentheses

\begin{tabular}{lcllll}
\hline Marsh \# & Area ha & $\begin{array}{l}\text { Conductivity } \\
\mathrm{mS} \mathrm{cm}^{-1}\end{array}$ & Sediment type & $\begin{array}{l}\text { Soil P } \\
\mathrm{mg} \mathrm{cm}^{-3}\end{array}$ & $\begin{array}{l}\text { Soil } \\
\mathrm{N} \mathrm{mg} \mathrm{cm}^{-3}\end{array}$ \\
\hline \multicolumn{2}{l}{ Low salinity } \\
F10 & 4.7 & $0.231(0.068)$ & Peaty clay & $0.09(0.01)$ & $3.88(0.68)$ \\
F12 & 11.3 & $0.658(0.164)$ & Marly clay & $0.09(0.01)$ & $3.31(1.01)$ \\
High salinity & & & & \\
F6 & 63.4 & $6.671(1.479)$ & Marl & $0.10(0.03)$ & $2.16(0.50)$ \\
F7 & 18.2 & $5.667(1.328)$ & Marl & $0.10(0.01)$ & $1.54(0.03)$ \\
\hline
\end{tabular}

primary production and litter nutrient content from 2006 were used to characterize the impact of macrophytes on the sediment microorganisms.

Root primary production was assessed in two marshes (high and low salinity) using mesh ingrowth cores (Steingrobe et al. 2000). Each ingrowth core $(4.3 \mathrm{~cm}$ diameter, $20 \mathrm{~cm}$ length) was constructed from $2 \times 3 \mathrm{~mm}$ flexible mesh screening and filled with root-free soil taken from each plot to match the mean bulk density of plot soils $(N=3)$. In each plot, three in-growth cores were inserted into cored holes and were left to incubate for 3 months. After this time, the cores were carefully removed and rinsed with marsh water. Roots protruding from the exterior were cut and the contents of each mesh core were sequentially washed through a $1 \mathrm{~mm}$ and $0.5 \mathrm{~mm}$ sieve. Living and dead roots were then separated from each sample using a two-phase decanting technique in Ludox TM-50, originally developed for mangrove roots (Robertson and Dixon 1993). As with the aboveground plant material, the separated roots were dried, weighed and ground. Due to the relatively small size of each sample, the ground roots were pooled by plots and then analyzed for nutrient content. From the remaining two marshes, roots were also non-quantitatively collected and analyzed for nutrient content. To gain annual root production rates, this process was repeated every three months throughout 2007.

\section{Chemical analyses}

Soil and plant total organic carbon (TOC) and total nitrogen (TN) were analyzed on a Carlo-Erba series 5,000 CHN-S analyzer. Soil samples were pretreated with $0.1 \mathrm{M} \mathrm{HCl}$ to remove carbonates. Available $\mathrm{C}$ was measured as organic $\mathrm{C}$ in $0.5 \mathrm{M} \mathrm{K}_{2} \mathrm{SO}_{4}$ extract (Ettema et al. 1999) using an organic $\mathrm{C}$ analyzer
(Shimadzu total organic carbon analyzer TOC5050A). Total phosphorus (soil P) was analyzed using ascorbic acid reduction of phosphomolybdate complex after acid digestion (McNamara and Hill 2000). Oxalate extractable sediment $\mathrm{P}\left(\mathrm{P}_{\mathrm{ox}}\right)$ was analyzed using ascorbic acid reduction of phosphomolybdenate complex in oxalate extracts (Owens et al. 1977). The $\mathrm{N}-\mathrm{NH}_{4}$ and $\mathrm{N}-\mathrm{NO}_{3}$ concentrations in $0.5 \mathrm{M} \mathrm{KCl}$ extract were analyzed by flow injection analyzer (FIAstar 5012, Foss Tecator, Sweden).

Nutrients in microbial biomass

We used two fumigation extraction procedures to determine microbial biomass carbon (MBC), nitrogen (MBN) and phosphorus (MBP) within 10-g of the refrigerated soil subsamples. $\mathrm{MBC}$ and $\mathrm{MBN}$ were calculated after subsequent $0.5 \mathrm{M} \mathrm{K}_{2} \mathrm{SO}_{4}$ extractions (Vance et al. 1987) as the difference in $\mathrm{K}_{2} \mathrm{SO}_{4}$ extractable $\mathrm{C}$ and $\mathrm{N}$ between the fumigated and unfumigated samples (Shimadzu total organic carbon analyzer TOC-5050A) and corrected by extraction efficiency factors of $k_{\mathrm{EC}}=0.37$ and $k_{\mathrm{EN}}=0.54$, respectively. The MBP was calculated after subsequent $\mathrm{NaHCO}_{3}$ extraction and quantification of $\mathrm{P}$ by the molybdophosphate complex method (Olsen and Sommers 1982). All biomass values were expressed per gram soil dry weight.

Nutritional status of microbial community

Phospholipid fatty acids (PLFA) were analyzed in $2 \mathrm{~g}$ of the refrigerated soil according to Frostegård et al. (1993). Phospholipids were separated, quantified and identified by gas chromatography (HP 6890 with flame ionization detector, FID). PLFA were identified by comparing the retention times of the sample with FAME standards (Supelco, Larodan Fine Chemicals 
$\mathrm{AB})$. The mol\% of terminally iso- and anteisobranched fatty acids was combined into terminally branched fatty acids group (TBFA; Haack et al. 1994) indicating the presence of amino acids in the environment as primers for TBFA formation (Kaneda 1991). The ratio of monounsaturated to saturated FAs (MUFA/STFA) was examined as it can change due to membrane changes in response to environmental stresses; where an increasing ratio signifies an increase in carbon (energy) availability (Kieft et al. 1997). Since the quantity of microbial PLFA is a function of microbial biomass (Zelles et al. 1992), we used the total amount of all bacterial PLFA identified in the samples as an index of live microbial biomass $\left(\mathrm{PLFA}_{\text {tot }}\right)$. The specific respiration rate $\left(\mathrm{CO}_{2}\right.$ per unit microbial biomass; $\mathrm{Q}_{\mathrm{CO} 2}$ ) was also calculated. Higher specific respiration rates indicate increasingly stressful environmental conditions to the microbial community (Anderson and Domsch 1990).

Microbial nutrient transformation

\section{Nitrogen mineralization}

Three week incubations of $10 \mathrm{~g}$ fresh soil subsamples in $100 \mathrm{~mL}$ flasks covered with perforated parafilm at $25^{\circ} \mathrm{C}$ in the dark were used for measuring net $\mathrm{N}$ mineralization rate (Ste-Marie and Paré 1999; Šantrůčková et al. 2001). Net mineralization rate was calculated as a difference between final (21 days) and beginning (7 days) concentrations of $\mathrm{N}-\mathrm{NH}_{4}$, divided by the number of days.

\section{Carbon mineralization}

Soil subsamples $(30 \mathrm{~g})$ were slowly stirred with $20 \mathrm{~mL}$ of physiological salt solution $(0.9 \% \mathrm{NaCl})$ in tightly closed $100 \mathrm{~mL}$ bottles incubated at $25^{\circ} \mathrm{C}$ in the dark. Incubations were conducted under both aerobic and anaerobic conditions. Aerobic respiration (aero$\mathrm{bCO}_{2}$ ) was measured under an atmosphere of $21 \% \mathrm{O}_{2}$ after $24 \mathrm{~h}$. Anaerobic conditions were achieved by bubbling the water phase of the samples with helium gas for $10 \mathrm{~min}$. Samples for anaerobic respiration (anaerobic $\mathrm{CO}_{2}$ ) and $\mathrm{CH}_{4}$ production (methanogenesis) were incubated for 14 days and gas production was measured using HP 5,890 gas chromatograph (Agilent, USA), with a thermal conductivity detector for $\mathrm{CO}_{2}$, and FID for $\mathrm{CH}_{4}$.
Denitrification enzyme activity (DEA)

Denitrification enzyme activity was measured using an acetylene-inhibition technique (Balderston et al. 1976). Ten grams of fresh weight soil were incubated in $100 \mathrm{~mL}$ flasks with $15 \mathrm{ml}$ of nutrient solution containing excess nitrate $\left(0.5 \mathrm{~g} \mathrm{l}^{-1} \mathrm{KNO}_{3}, 1 \mathrm{~g} \mathrm{l}^{-1}\right.$ glucose). At the start of experiment, $10 \%$ of the gas phase of the samples was replaced with acetylene. The production of nitrous oxide was taken $(0.2 \mathrm{ml})$ and measured from the headspace at time zero and after 30 and 60 min using a HP 6,890 gas chromatograph equipped with an electron capture detector.

\section{Nitrogenase activity (NA)}

To measure potential nitrogenase activity, we used a modification of the acetylene reduction assay method (Hardy et al. 1968). Glucose (0.184-0.696 mg C g ${ }^{-1}$ ) was mixed into the $50 \mathrm{~g}$ of fresh soil and sealed in $100 \mathrm{~mL}$ glass bottles, which were equilibrated to atmospheric pressure. From each bottle, $30 \mathrm{ml}$ of the headspace was removed and subsequently replaced with $20 \mathrm{ml}$ of $\mathrm{N}_{2}$ gas to lower the partial pressure of oxygen. Ten $\mathrm{mL}$ of acetylene, freshly prepared from $\mathrm{CaC}_{2}$, were added to each bottle, which were then vigorously shaken for $1 \mathrm{~min}$, and incubated under dark conditions at $28^{\circ} \mathrm{C}$. Bottles were shaken again after $12 \mathrm{~h}$ and at the end of the incubation. After $24 \mathrm{~h}$, approximately $15 \mathrm{ml}$ of headspace were withdrawn and analyzed using a Shimadzu 14 gas chromatograph, equipped with FID. Controls run with samples without acetylene as well as blanks showed no endogenous ethylene production. Rates of acetylene reduction were expressed as nmol of acetylene reduced per gram dry mass of sample per day of incubation.

\section{Data analysis}

Two-way ANOVAs, with Neumann-Keuls Post Hoc tests, were used (STATISTICA version 7.0) to evaluate: (1) the effect of $P$ addition and salinity comparing LP/E and HP/E plots at the high and low salinity sites; and (2) the effect of plant species and salinity comparing HP/E and HP/T at the high and low salinity sites on sediment characteristics and microbial communities and processes. We could not use a 3-way ANOVA due to the unbalanced design (there is no 
combination of low $\mathrm{P}$ and Typha). Root production data were Box-Cox transformed to meet the assumptions of normality and homoscedasticity. Root tissue nutrients could not be statistically tested, as the samples were pooled for each plot, but data were correlated to shoot tissue.

\section{Results}

$\mathrm{P}$ addition and salinity effect

$\mathrm{P}$ addition significantly increased aboveground biomass production (NPPshoot; Table 2a\&b). It also significantly increased $\mathrm{P}$ content and slightly increased $\mathrm{N}$ content of live tissue (data not shown, but see Rejmánková et al. 2008), and because live and dead tissue nutrient content is closely correlated, the same increase was observed in the senescent tissue (litter) (Table 2a\&b). The increase of shoot $\mathrm{P}$ content was much higher than that of $\mathrm{N}$ leading to highly significant changes in shoot nutrient ratios, especially $\mathrm{C} / \mathrm{P}$ and $\mathrm{N} / \mathrm{P}$, which decreased up to more than fivefold (Table 2a). There was no, or marginal effect of salinity on litter nutrients with the exception of $\mathrm{C} / \mathrm{P}$ ratio which was lower at high salinity marshes (Table 2a\&b). Neither $\mathrm{P}$ addition, nor salinity had a significant effect on root production (Table $2 b$ ). However, the ratios of roots to shoots dramatically decreased in response to $\mathrm{P}$ (Table $2 \mathrm{a} \& \mathrm{~b}$ ). Senescent root nutrient content, specifically $\mathrm{P}$ and $\mathrm{C} / \mathrm{P}$ were closely correlated with senescent shoot nutrient contents $\left(R^{2}=0.877 ; P=0.02 ; N=6\right.$, and $R^{2}=0.848$; $P=0.09 ; N=6$ for tissue $\mathrm{P}$ and $\mathrm{C} / \mathrm{P}$, respectively; data not shown).

From measured chemical parameters of the sediment, $\mathrm{P}$ addition positively affected mainly $\mathrm{P}_{\mathrm{ox}}$, whose concentration increased by about an order of magnitude over LP, and also TOC and TN contents (Table $3 \mathrm{a} \& \mathrm{~b}$ ). $\mathrm{C}$ avail increased with $\mathrm{P}$ addition, but only in the low salinity plots (Table $3 a \& b$ ). The nitrate content was significantly lower in the high salinity than in the low plots (Table $3 a \& b$ ). The nitrate content increased in the P-added plots only for the high salinity sites while it decreased in the low salinity sites (Table 3a). Nutrient and C contents were, in general, lower at high salinity (Table 3a). Ammonium content was not significantly affected by $\mathrm{P}$ or salinity (Table 3a, b).
Microbes responded to the altered nutrient availability in the sediment of the P-added plots with a significant increase of $\mathrm{MBC}, \mathrm{MBN}, \mathrm{MBP}$, while microbial biomass, indicated by PLFA $_{\text {tot }}$, did not significantly change (Table $4 a \& b$ ). The increase in MBC and MBP was salinity dependent with significantly higher values at the low salinity sites (Table 4a\&b). Similar to plant $\mathrm{C} / \mathrm{P}$ ratios, microbial MBC/MBP significantly decreased at the HP plots, and the ratio was lower at high salinity (Table $4 \mathrm{a} \& \mathrm{~b}$ ). Similar to plant $\mathrm{C} / \mathrm{N}, \mathrm{MBC} / \mathrm{MBN}$ was not affected by $\mathrm{P}$ addition (Table $4 \mathrm{a} \& \mathrm{~b}$ ). MBC/MBN was significantly lower, however, in high salinity marshes. Both MBN and MBC were lower at high salinities, while PLFA $_{\text {tot }}$ was higher at high salinity (Table $4 \mathrm{a} \& \mathrm{~b}$ ).

The effect of $\mathrm{P}$ addition on microbial community nutritional status was indicated by an increase of MUFA/STFA ratio and by a decrease of PLFA $_{\text {tot }}$ t MBC (Table 5a\&b). While the response of PLFA ${ }_{\text {tot }}$ t MBC to $\mathrm{P}$ was salinity dependent, the response of MUFA/STFA and $\mathrm{Q}_{\mathrm{CO} 2}$ were not. Salinity per se negatively affected MBC/TOC and enhanced all other parameters related to the nutritional status of microbial community ( $\mathrm{PLFA}_{\text {tot }}$ MBC, $\mathrm{Q}_{\mathrm{CO} 2}$, and TBFA).

Nitrogen mineralization, denitrification enzyme activity, nitrogenase activity and methanogenesis were enhanced by $\mathrm{P}$ addition, while aerobic and anaerobic respiration were not significantly affected (Table 6a\&b). Salinity decreased N mineralization, denitrification enzyme activity and methanogenesis and weakened the positive effect of $\mathrm{P}$ addition on these processes (Table $6 \mathrm{a} \& \mathrm{~b}$ ).

\section{Plant species and salinity effects}

Eleocharis and Typha had similar shoot and root production (NPPshoot, NPProot, respectively) at the high salinity sites, but Eleocharis had a higher production at the low salinity sites (Table 2a\&c). Shoot litter of Typha, as compared to Eleocharis, had slightly but significantly higher $\mathrm{C}$ content and similar $\mathrm{P}$ content. Shoot litter $\mathrm{N}$ content was slightly greater at high salinity sites, but there were no significant differences in $\mathrm{C}$ and $\mathrm{P}$ of litter. Both species had similar root $\mathrm{N}$ content that was comparable with shoot $\mathrm{N}$, but Typha had always almost two times higher root P content than Eleocharis (data not shown). Eleocharis also had higher ratios of root to shoot biomass compared to Typha (Table 2a). 
Table 2 Aboveground primary production $\left(\mathrm{NPP}_{\text {shoot }}\right.$, data from 2006), root production ( $\mathrm{NPP}_{\text {root }}$ ) and litter carbon (C), nitrogen (N) and phosphorus (P) contents, for low and high salinity marshes and three different treatments: $P$ unenriched sites dominated by Eleocharis cellulosa (LP/E) and P enriched sites dominated either by E. cellulosa (HP/E) or Typha domingensis (HP/T). NPP values are averages of $N=4$ (two marshes and two sampling dates, February and August 2006) except for root production, which was measured only in two marshes, from high and low salinity each. Nutrient data are replicates from two marshes. Section 2a refers to treatment means; section $2 \mathrm{~b}$ refers to $p$-values of $\mathrm{P}$ addition and salinity effect; section $2 \mathrm{c}$ refers to $p$-values of plant species and salinity effect; "ns" means $P>0.05$ (ANOVA)

\begin{tabular}{|c|c|c|c|c|c|c|c|c|c|c|}
\hline & \multirow[t]{2}{*}{ Salinity } & \multirow{2}{*}{$\begin{array}{l}\mathrm{NPP}_{\text {root }} \\
\mathrm{g} \mathrm{m}^{-2} \mathrm{y}^{-1}\end{array}$} & \multirow{2}{*}{$\begin{array}{l}\mathrm{NPP}_{\text {shoot }} \\
\mathrm{g} \mathrm{m}^{-2} \mathrm{y}^{-1}\end{array}$} & \multirow[t]{2}{*}{ Root/Shoot } & \multicolumn{6}{|c|}{ Litter nutrients (\% dry mass) } \\
\hline & & & & & $\mathrm{C}$ & $\mathrm{N}$ & $\mathrm{P}$ & $\mathrm{C} / \mathrm{N}$ & $\mathrm{C} / \mathrm{P}$ & $\mathrm{N} / \mathrm{P}$ \\
\hline \multicolumn{11}{|c|}{ 2a Treatment means } \\
\hline $\mathrm{LP} / \mathrm{E}$ & Low & 260 & 120.1 & 2.8 & 43.3 & 0.46 & 0.007 & 95.2 & $6,404.5$ & 68.1 \\
\hline $\mathrm{HP} / \mathrm{E}$ & Low & 516 & 481.3 & 0.7 & 44.4 & 0.56 & 0.033 & 86.6 & $1,865.5$ & 19.9 \\
\hline $\mathrm{HP} / \mathrm{T}$ & Low & 148 & 217.9 & 0.5 & 47.4 & 0.47 & 0.031 & 103.1 & $1,554.8$ & 15 \\
\hline $\mathrm{LP} / \mathrm{E}$ & High & 251 & 88.4 & 2.2 & 43.7 & 0.55 & 0.012 & 80.6 & $3,644.9$ & 46.7 \\
\hline $\mathrm{HP} / \mathrm{E}$ & High & 167 & 237.5 & 1.1 & 43.3 & 1.05 & 0.053 & 42.3 & 819.1 & 20.2 \\
\hline $\mathrm{HP} / \mathrm{T}$ & High & 176 & 377.8 & 0.7 & 46.1 & 0.59 & 0.05 & 75.5 & 950.2 & 13.7 \\
\hline \multicolumn{11}{|c|}{$2 \mathrm{~b} p$-values - effect of $\mathrm{P}$ addition and salinity } \\
\hline$P$ effect & & $\mathrm{ns}$ & 0.006 & & ns & $\mathrm{ns}$ & 0.018 & ns & 0.004 & 0.015 \\
\hline Salinity effect & & $\mathrm{ns}$ & 0.043 & & $\mathrm{~ns}$ & ns & ns & $\mathrm{ns}$ & 0.04 & ns \\
\hline P Salinity & & ns & ns & & ns & ns & ns & ns & ns & $\mathrm{ns}$ \\
\hline \multicolumn{11}{|c|}{ 2c p-values - effect of plant species and salinity } \\
\hline Plant effect & & ns & ns & & 0.006 & ns & ns & ns & ns & ns \\
\hline Salinity effect & & ns & ns & & $\mathrm{ns}$ & ns & ns & ns & ns & ns \\
\hline Plant $\times$ salinity & & $\mathrm{ns}$ & $\mathrm{ns}$ & & ns & $\mathrm{ns}$ & ns & ns & $\mathrm{ns}$ & $\mathrm{ns}$ \\
\hline
\end{tabular}

The effect of plant species on chemical and microbial characteristics of the sediment was generally lower than the effect of $\mathrm{P}$ addition, which was mainly evident at the low salinity sites (Tables 3b\&c, $4 \mathrm{~b} \& \mathrm{c}$, and $5 \mathrm{~b} \& \mathrm{c})$. As compared to Eleocharis plots, Typha plots were significantly higher in $\mathrm{P}_{\text {ox }}$ content at both salinity levels and in TOC at only low salinity (Table 3a\&c). Other sediment nutrients were unaffected by plant species (Table 3c). The contents of TOC, TN and $\mathrm{P}_{\mathrm{ox}}$ were generally lower at high salinity sites (Table 3a).

In Typha plots, MBN and microbial biomass, indicated by $\mathrm{PLFA}_{\text {tot }}$, were higher, but $\mathrm{MBC} / \mathrm{MBN}$ ratio was lower than in Eleocharis plots (Table 4a). Conversely, phosphorus immobilization in microbial cells, indicated by higher MBP and lower MBC/MBP, was enhanced in Eleocharis plots. All the above differences were more distinctive at the low salinity sites (Table 4a). High salinity weakened plant species effect in all cases but PLFA tot $_{\text {. }}$.

Microbial community nutritional status was not affected by plant species (Table $5 \mathrm{c}$ ). It was negatively influenced by high salinity, as indicated by lower $\mathrm{MBC} / \mathrm{TOC}$ ratio and higher $\mathrm{PLFA}_{\text {tot }} / \mathrm{MBC}, \mathrm{Q}_{\mathrm{CO} 2}$ and proportion of TBFA groups (Table $5 \mathrm{a} \& \mathrm{c}$ ).

Impact of plant species on microbial processes was not consistent and was largely insignificant (Table 6c). The exception was NA and SRB; NA was significantly higher while the mol\% of the SRB biomarker was lower in the soil from the Eleocharis plots (Table 6a). Typha supported denitrification enzyme activity and respiration (both aerobic and anaerobic), and reduced methanogenesis at the low salinity sites, while its influence was opposite at the high salinity sites (Table 6a\&c). High salinity mostly reduced the rate of the microbial processes (Table 6a).

\section{Discussion}

$P$ addition effect

In the studied marshes, $\mathrm{P}$ addition significantly increased aboveground production and ratio of shoot 
Table 3 Chemical parameters in the sediment $(1-10 \mathrm{~cm})$ for low and high salinity marshes and three different treatments: $\mathrm{P}$ unenriched sites dominated by Eleocharis cellulosa $(\mathrm{LP} / \mathrm{E})$ and $\mathrm{P}$ enriched sites dominated either by E. cellulosa (HP/E) or Typha domingensis (HP/
T). Values are averages of $N=6$ (three replicates from two marshes). Section 3a refers to treatment means; section $3 \mathrm{~b}$ refers to $p$-values of $\mathrm{P}$ addition and salinity effect; section $3 \mathrm{c}$ refers to $p$-values of plant species and salinity effect; "ns" means $P>0.05$ (ANOVA)

\begin{tabular}{|c|c|c|c|c|c|c|c|}
\hline & Salinity & TOC & $\mathrm{TN}$ & $\mathrm{C}$ avail & $\mathrm{P}_{\mathrm{ox}}$ & $\mathrm{NH}_{4}-\mathrm{N}$ & $\mathrm{NO}_{3}-\mathrm{N}$ \\
\hline \multicolumn{8}{|l|}{ 3a Treatment means } \\
\hline $\mathrm{LP} / \mathrm{E}$ & Low & 110.20 & 9.16 & 43.0 & 0.76 & 2.75 & 1.88 \\
\hline $\mathrm{HP} / \mathrm{E}$ & Low & 195.0 & 11.51 & 238.6 & 7.30 & 3.25 & 0.70 \\
\hline $\mathrm{HP} / \mathrm{T}$ & Low & 219.9 & 12.98 & 250.3 & 16.11 & 1.50 & 0.45 \\
\hline $\mathrm{LP} / \mathrm{E}$ & High & 145.50 & 5.08 & 185.3 & 0.93 & 2.47 & 0.03 \\
\hline $\mathrm{HP} / \mathrm{E}$ & High & 165.4 & 6.87 & 172.2 & 6.17 & 2.84 & 0.20 \\
\hline $\mathrm{HP} / \mathrm{T}$ & High & 163.8 & 7.26 & 111.0 & 9.03 & 2.06 & 0.16 \\
\hline \multicolumn{8}{|c|}{$3 \mathrm{~b} p$-values - effect of $\mathrm{P}$ addition and salinity } \\
\hline Phosphorus effect & & 0.0001 & 0.016 & 0.0001 & 0.0001 & ns & 0.027 \\
\hline Salinity effect & & ns & 0.0001 & ns & ns & ns & 0.0001 \\
\hline Phosphorus $\times$ Salinity & & 0.0001 & ns & 0.0001 & 0.029 & ns & 0.006 \\
\hline \multicolumn{8}{|c|}{$3 \mathrm{c} p$-values - effect of plant species and salinity } \\
\hline Plant effect & & 0.032 & ns & ns & 0.0001 & ns & ns \\
\hline Salinity effect & & 0.0001 & 0.0001 & 0.0001 & 0.0001 & ns & ns \\
\hline Plant $\times$ salinity & & 0.017 & ns & $\mathrm{ns}$ & 0.0001 & $\mathrm{~ns}$ & ns \\
\hline
\end{tabular}

TOC, $T N$ total organic carbon and total nitrogen in $\mathrm{mg} \mathrm{g}^{-1} ; \mathrm{C}$ avail available carbon, $P_{o x}$ oxalate extractable phosphorus, $N H_{4}-N$, $\mathrm{NO}_{3}-\mathrm{N}$ ammonium and nitrate nitrogen, all in $\mu \mathrm{g} \mathrm{g}$

Table 4 Microbial biomass and microbial biomass nutrients in low and high salinity marshes and three different treatments: $\mathrm{P}$ unenriched sites dominated by Eleocharis cellulosa (LP/E) and $\mathrm{P}$ enriched sites dominated either by E. cellulosa (HP/E) or Typha domingensis $(\mathrm{HP} / \mathrm{T})$. Values are averages of $N=6$ (three replicates from two marshes). Section $4 \mathrm{a}$ refers to treatment means; section $4 \mathrm{~b}$ refers to $\mathrm{p}$-values of $\mathrm{P}$ addition and salinity effect; section $4 \mathrm{c}$ refers to $p$-values of plant species and salinity effect; "ns" means $P>0.05$ (ANOVA)

\begin{tabular}{|c|c|c|c|c|c|c|c|}
\hline & Salinity & $\mathrm{MBC}$ & $\mathrm{MBN}$ & MBP & $\mathrm{MBC} / \mathrm{MBN}$ & $\mathrm{MBC} / \mathrm{MBP}$ & PLFA $_{\text {tot }}$ \\
\hline \multicolumn{8}{|l|}{ 4a Treatment means } \\
\hline $\mathrm{LP} / \mathrm{E}$ & Low & 2,601 & 81.8 & 2.71 & 31.8 & 959.8 & 94.4 \\
\hline $\mathrm{HP} / \mathrm{E}$ & Low & 4,583 & 146 & 32.60 & 31.4 & 140.6 & 131.2 \\
\hline $\mathrm{HP} / \mathrm{T}$ & Low & 5,390 & 240 & 7.70 & 22.5 & 700.0 & 224.3 \\
\hline $\mathrm{LP} / \mathrm{E}$ & High & 657.0 & 56.0 & 2.39 & 11.7 & 274.9 & 218.5 \\
\hline $\mathrm{HP} / \mathrm{E}$ & High & 1,117 & 121 & 18.80 & 9.2 & 59.4 & 212.0 \\
\hline $\mathrm{HP} / \mathrm{T}$ & High & 1,202 & 153 & 4.65 & 7.9 & 258.5 & 221.7 \\
\hline \multicolumn{8}{|c|}{$4 \mathrm{~b} p$-values - effect of $\mathrm{P}$ addition and salinity } \\
\hline Phosphorus effect & & 0.0001 & 0.0001 & 0.0001 & ns & 0.0001 & ns \\
\hline Salinity effect & & ns & 0.012 & 0.027 & 0.0001 & 0.0001 & 0.0001 \\
\hline Phosphorus $\times$ Salinity & & 0.0001 & ns & 0.034 & $\mathrm{~ns}$ & 0.0001 & ns \\
\hline \multicolumn{8}{|c|}{$4 \mathrm{c} p$-values - effect of plant species and salinity } \\
\hline Plant effect & & ns & 0.0003 & 0.0001 & 0.028 & 0.0001 & 0.0083 \\
\hline Salinity effect & & 0.0001 & 0.0001 & 0.0107 & 0.0012 & 0.0001 & 0.037 \\
\hline Plant $\times$ Salinity & & ns & 0.0413 & 0.087 & $\mathrm{~ns}$ & 0.0029 & 0.0275 \\
\hline
\end{tabular}

$M B C, M B N$, and $M B P$ microbial carbon, nitrogen, and phosphorus, respectively, in $\mu \mathrm{g} \mathrm{g}^{-1} ;$ PLFAtot total amount of phospholipids fatty acids in nmol PLFA $^{-1}$ 
Table 5 Parameters related to the status of microbial community for low and high salinity marshes and three different treatments: $\mathrm{P}$ unenriched sites dominated by Eleocharis cellulosa (LP/E) and $\mathrm{P}$ enriched sites dominated either by E. cellulosa (HP/E) or Typha domingensis $(\mathrm{HP} / \mathrm{T})$. Values are averages of $N=6$ (three replicates from two marshes). Section 5a refers to treatment means; section $5 \mathrm{~b}$ refers to $\mathrm{p}$-values of $\mathrm{P}$ addition and salinity effect; section $5 \mathrm{c}$ refers to $p$-values of plant species and salinity effect; "ns" means $P>0.05$ (ANOVA)

\begin{tabular}{|c|c|c|c|c|c|c|}
\hline & Salinity & $\mathrm{MBC} / \mathrm{TC}$ & PLFAtot/MBC & $\mathrm{Q}_{\mathrm{CO} 2}$ & MUFA/STFA & TBFA \\
\hline \multicolumn{7}{|l|}{ 5A Treatment means } \\
\hline $\mathrm{LP} / \mathrm{E}$ & Low & 0.023 & 0.036 & 0.060 & 0.605 & 16.01 \\
\hline $\mathrm{HP} / \mathrm{E}$ & Low & 0.023 & 0.029 & 0.037 & 0.759 & 17.26 \\
\hline $\mathrm{HP} / \mathrm{T}$ & Low & 0.024 & 0.042 & 0.059 & 0.866 & 17.13 \\
\hline $\mathrm{LP} / \mathrm{E}$ & High & 0.004 & 0.333 & 0.231 & 0.657 & 22.80 \\
\hline $\mathrm{HP} / \mathrm{E}$ & High & 0.006 & 0.189 & 0.211 & 0.847 & 21.61 \\
\hline $\mathrm{HP} / \mathrm{T}$ & High & 0.007 & 0.184 & 0.112 & 0.802 & 22.30 \\
\hline \multicolumn{7}{|c|}{$5 \mathrm{~b} p$-values - effect of $\mathrm{P}$ addition and salinity } \\
\hline Phosphorus effect & & ns & 0.0001 & ns & 0.0002 & ns \\
\hline Salinity effect & & 0.0001 & 0.0001 & 0.0001 & 0.033 & 0.001 \\
\hline Phosphorus $\times$ salinity & & ns & 0.0001 & ns & ns & ns \\
\hline \multicolumn{7}{|c|}{5 c $p$-values - effect of plant species and salinity } \\
\hline Plant effect & & ns & ns & $\mathrm{ns}$ & ns & ns \\
\hline Salinity effect & & 0.0001 & 0.0001 & 0.0001 & ns & 0.0014 \\
\hline Plant $\times$ salinity & & ns & ns & 0.0049 & ns & ns \\
\hline
\end{tabular}

$M B C$ microbial carbon; TOC total sediment carbon; PLFAtot/MBC active/total biomass in nmol ${ }_{\mathrm{PLFA}} \mu \mathrm{g}^{-1} \mathrm{C} ; Q_{\mathrm{CO} 2}$ specific respiration rate in $\mathrm{d}^{-1} ;$ MUFA/STFA ratio of Monounsaturated and Saturated fatty acids; TBFA terminally branched fatty acids in mol\%

Table 6 Parameters related to nutrient mineralization and transformation processes for low and high salinity marshes and three different treatments: $\mathrm{P}$ unenriched sites dominated by Eleocharis cellulosa (LP/E) and $\mathrm{P}$ enriched sites dominated either by E. cellulosa (HP/E) or Typha domingensis (HP/T).
Values are averages of $N=6$ (three replicates from two marshes). Section $6 \mathrm{a}$ refers to treatment means; section $6 \mathrm{~b}$ refers to $p$ values of $\mathrm{P}$ addition and salinity effect; section $6 \mathrm{c}$ refers to $\mathrm{p}$ values of plant species and salinity effect; "ns" means $P>0.05$ (ANOVA)

\begin{tabular}{|c|c|c|c|c|c|c|c|c|}
\hline & Salinity & Nmin & DEA & NA & AnaerobCO 2 & AerobCO $_{2}$ & $\mathrm{CH}_{4}$ & SRB \\
\hline \multicolumn{9}{|l|}{ 6a Treatment means } \\
\hline $\mathrm{LP} / \mathrm{E}$ & Low & -441.3 & 36.70 & 1.12 & 12.10 & 193.90 & 0.055 & 10.5 \\
\hline $\mathrm{HP} / \mathrm{E}$ & Low & 75.60 & 68.70 & $1,158.0$ & 15.90 & 160.60 & 2.70 & 8.13 \\
\hline $\mathrm{HP} / \mathrm{T}$ & Low & 76.40 & 87.30 & 154.30 & 20.10 & 281.90 & 1.84 & 13.1 \\
\hline $\mathrm{LP} / \mathrm{E}$ & High & -225.3 & 25.20 & 1.18 & 14.40 & 150.30 & 0.034 & 9.39 \\
\hline $\mathrm{HP} / \mathrm{E}$ & High & 61.90 & 39.20 & 816.0 & 15.70 & 230.10 & 0.073 & 9.78 \\
\hline $\mathrm{HP} / \mathrm{T}$ & High & 73.70 & 23.80 & 73.0 & 12.40 & 132.90 & 0.195 & 10.7 \\
\hline \multicolumn{9}{|c|}{$6 \mathrm{~b} p$-values - effect of $\mathrm{P}$ addition and salinity } \\
\hline Phosphorus effect & & 0.0001 & 0.0001 & 0.0001 & ns & ns & 0.0002 & ns \\
\hline Salinity effect & & 0.0001 & 0.0005 & ns & ns & ns & 0.0002 & ns \\
\hline Phosphorus $\times$ salinity & & 0.003 & 0.012 & ns & ns & ns & 0.0002 & ns \\
\hline \multicolumn{9}{|c|}{ 6c $p$-values - effect of plant species and salinity } \\
\hline Plant effect & & $\mathrm{ns}$ & ns & 0.0001 & ns & ns & ns & 0.034 \\
\hline Salinity effect & & ns & 0.0001 & 0.0001 & 0.043 & ns & 0.0001 & ns \\
\hline Plant $\times$ salinity & & ns & 0.046 & $\mathrm{~ns}$ & $\mathrm{~ns}$ & 0.0005 & $\mathrm{~ns}$ & $\mathrm{~ns}$ \\
\hline
\end{tabular}

Nmin nitrogen mineralization rate, $\mathrm{ng} \mathrm{N}-\mathrm{NH} 4 \mathrm{~g}^{-1} \mathrm{~d}^{-1} ; D E A$ denitrification enzyme activity, $\mathrm{ng} \mathrm{N}_{2} \mathrm{O} \mathrm{g}^{-1} \mathrm{~d}^{-1} ; N A$ nitrogenase activity, nmol $\mathrm{C}_{2} \mathrm{H}_{4} \mathrm{~g}^{-1} \mathrm{~d}^{-1} ;$ AnaerobCO $\mathrm{O}_{2}$ anaerobic respiration rate and AerobCO $\mathrm{O}_{2}$ aerobic respiration rate in $\mu \mathrm{g} \mathrm{CO}_{2} \mathrm{~g}^{-1} \mathrm{~d}^{-1} ; \mathrm{CH}_{4}$ methanogenesis, $\mu \mathrm{g} \mathrm{CH}_{4} \mathrm{~g}^{-1} \mathrm{~d}^{-1} ; S R B$ sulfate reducing bacteria, $\mathrm{mol} \%$ 
to root; the increased shading led to the elimination of cyanobacteria (see also Rejmánková et al. 2008). This switch from microphyte to macrophyte dominated autotrophic production gradually led to an increase of total $\mathrm{C}$ and $\mathrm{N}$ contents and availability in soil, and microbial nutrient contents. The same trend was also observed in similar wetlands such as the Florida Everglades (Davis 1991; DeBusk and Reddy 1998).

The addition of readily hydrolysable nutrients and the increase of nutrient availability has been reported to augment microbial growth (Anderson and Domsch 1985), increase organic matter turnover (Reddy et al. 1999), and accelerate the mineralization and release of nutrients back to the environment. Plants are an essential source of the organic carbon in soil. Any increase in plant production increases the $\mathrm{C}$ supply for microorganisms thus enhancing the development and activity of the microbial community. The rate at which this occurs further depends on plant material quality and nutrient availability in soil. Accordingly, we found that where plant production increased, there was an increase in microbial biomass. The level of microbial biomass $\mathrm{C}$ and $\mathrm{N}$ ( $\mathrm{MBC}$ and $\mathrm{MBN}$ ) was similar to what has been reported from the Everglades (Wright and Reddy 2001; Corstanje et al. 2007). In accordance with our primary hypothesis, microbial biomass $\mathrm{C}, \mathrm{N}$ and $\mathrm{P}$ and microbial activities were positively affected by $\mathrm{P}$ addition supporting the assumption that $\mathrm{P}$ is the limiting nutrient to the microbial biomass in unimpacted Belize marsh sediments. $\mathrm{P}$ limitation is further confirmed by decrease of $\mathrm{C} / \mathrm{P}$ ratio in microbial biomass (MBC/MBP) in $\mathrm{P}$ enriched soils. Although $\mathrm{P}$ immobilization into microbial biomass increased after $\mathrm{P}$ addition, MBP was still an order of magnitude lower than what has been found in the Everglades (Corstanje et al. 2007). This discrepancy perhaps can be linked to the amount of time $\mathrm{P}$ has been augmented within the systems. While our experimental plots have been enriched for only several years, the Everglades has been enriched by $\mathrm{P}$ for several decades.

In the studied $\mathrm{P}$ enriched plots, $\mathrm{N}$ mineralization, nitrogenase activity and denitrification enzyme activity were accelerated, which confirms our secondary hypothesis. These processes were most likely accelerated by plants, which contributed higher quantity and better quality biomass in $\mathrm{P}$ enriched plots. The enhancement of heterotrophic microbial activity by $\mathrm{P}$ additions or in high $\mathrm{P}$ soils has been well documented
(Bridgham and Richardson 1992; DeBusk and Reddy 1998; Bastviken et al. 2005). The increased input of easily decomposable plant material and rhizodeposition (Kozub and Liehr 1999) and resulting lower oxygen concentrations (Nielsen 1990) may have been the main drivers for the recorded changes in $\mathrm{N}$ cycle processes.

We also detected an increase in methanogenesis within the $\mathrm{P}$ enriched plots. Methanogenesis and most likely sulfate reduction are the major anaerobic processes governing carbon cycling in wetland ecosystems. Traditionally in highly reduced freshwater wetlands with low sulfate input, methanogenesis is considered the dominant carbon mineralization process, while in marine and salt marshes with a higher sulfate input, sulfate reduction is the dominant process (Ward and Winfrey 1985). Sulfate reduction was not measured in our study, but its occurrence was suggested by the presence of sulfate reducing bacteria (SRB, 10Me16:0 biomarker, Table 6a). The wetlands in Belize generally have high sulfate due to a significant proportion of gypsum in the underlaying rock; high rates of $\mathrm{H}_{2} \mathrm{~S}$ production have been documented at these sites (Rejmánková and Post 1996). In contrast to results of Drake et al. (1996) sulfate reduction potential (the distribution of SRB) was not enhanced by $\mathrm{P}$ addition.

The anaerobic respiration (anaerobic $\mathrm{CO}_{2}$ production rate) in our study was about $10 \%$ of the aerobic respiration rate (Table 6a). DeBusk and Reddy (1998) found anaerobic $\mathrm{CO}_{2}$ production rates to be $32 \%$ of the aerobic rates in the Everglades soils, while Benner et al. (1984) found values of $37 \%$. Others have reported values of 34-63\% (Bridgham and Richardson 1992) and 64\% (Wright and Reddy 2001). The lower values of anaerobic respiration we found are likely due to the lower organic matter content (supply of electron donors) of Belizean soils and most likely also by lower $\mathrm{C}$ availability as compared to more peaty sediments studied elsewhere.

A great deal of energy is needed to support microbial growth and activities. The biochemical transformation of saturated fatty acids to monounsaturated fatty acids requires available energy and oxygen (Fulco and Bloch 1964), which justifies using the ratio of soil monounsaturated/saturated fatty acids (MUFA/STFA) to identify increasing substrate availability in the system. A relationship between MUFAs and high substrate availability was also identified by 
Zelles et al. (1992) in agriculture soil, and Bossio and Scow (1998) found MUFA to increase with added carbon in wetland conditions. We found this ratio to increase in $\mathrm{P}$ enriched sites.

Plant species effect

Based on previous results (Rejmánková 2005; Rejmánková et al. 2008) that showed different biomass production, nutrient uptake and resorption from senescing tissues of Typha and Eleocharis, we expected different quality and quantity of their litter to affect microbial biomass and activity. This assumption has not been validated by this study. The differences in biomass production between the two species were not significant; largely because the Typha plots were not fully established (the biomass production of a well established Typha stand in the Everglades is around 2,500 g/ $/ \mathrm{m}^{2} / \mathrm{y}$; Weisner and Miao 2004). In terms of nutrients in senescent biomass, there were no differences between the species in $\mathrm{N}$ and $\mathrm{P}$, but Typha litter contained consistently more $\mathrm{C}$. The relatively weak plant species effect on microbial biomass and processes corresponded to small differences in plant litter stoichiometry.

Regardless of plant litter similarities, plant species significantly impacted the transformation of $\mathrm{P}$, particularly SRP, MBP contents and MBC/MBP ratio in the sediment. This effect might be explained by the macrophytes different life strategies with respect to $\mathrm{P}$ use efficiency and allocation. Typha behaves as a competitor (sensu Grime 2001). Accordingly, compared to Eleocharis, Typha's P use efficiency and $\mathrm{P}$ uptake was lower (more inorganic P left behind in sediment, see Table 3a). P resorption efficiency was also lower (unpublished data and Rejmánková 2005). Moreover, microbial P immobilization in Typha plots was lower, even though more reactive $\mathrm{P}$ was in the sediment. We also found that Typha released less extracellular phosphatases than Eleocharis (Rejmánková and Macek 2008). The higher $P$ use and resorption efficiency of Eleocharis confirmed the status of this species as a stress tolerator.

The higher MBN in Eleocharis plots was most likely supported by the more $\mathrm{N}$ available due to an order of magnitude higher nitrogenase activity compared to Typha plots (Table 6a). The uptake of $\mathrm{N}$ by macrophytes was comparable (see Table 2a), therefore, it is likely that more available $\mathrm{N}$ within Eleocharis plots was immobilized into microbial biomass. This further bolsters the role of Eleocharis as a stress tolerator, supporting microbial nutrient immobilization to keep microorganisms in fast turnover.

Salinity effect

The rate and direction of the changes in microbial activities and biomass were found, as hypothesized, to be salinity dependent. In low salinity marshes, we found a significant increase in microbial biomass and microbial processes within $\mathrm{P}$ added plots. This suggests that low salinity marshes are microbiologically more active, with a higher release of nutrients back to the environment (higher ratio of $\mathrm{MBC} / \mathrm{MBN}$, $\mathrm{MBC} / \mathrm{MBP}$ ). Lower activity at high salinity plots is significant for lower $\mathrm{N}$ mineralization, denitrification enzyme activity and methanogenesis. The other measured processes (nitrogenase activity, aerobic and anaerobic respiration) tended to be lower too, but the difference was not significant.

In the high salinity marshes, the microbial growth was limited, resulting in lower microbial biomass to total $\mathrm{C}$ ratio (Table 5a). This ratio is an indicator of $\mathrm{C}$ availability and the ability of microbes to utilize it; lower ratios imply lower C availability (Anderson and Domsch 1989). High salinity marshes also had distinctly higher PLFA tot to MBC ratios (Table 5). We suggest that high PLFA $_{\text {tot }}$ to MBC ratio indicates higher proportion of membrane phospholipids in total biomass due to lower bacterial size in high salinity soils. According to Zahran (1997), the morphology of the bacteria is usually modified with increasing salinity of the environment; cells usually shrink and change in cell and cytoplasm volume. Consequently, a close correlation between microbial biomass MBC and PLFA ${ }_{\text {tot }}$ should not be expected (Calderon et al. 2001). Accordingly, we can speculate that even a lower amount of microbial cells of smaller size, with a lower C content, could have higher amount of phosholipids in the membranes (Table 5a).

The chemical composition of membranes may also be modified by salinity, as demonstrated by an increased portion of TBFA in samples from high salinity sites (Table 5a). To create TBFA, amino acid precursors are required (Kaneda 1991). At the same time, some amino acids are considered to be essential osmolytes for bacteria to adapt to saline environments (Imhoff 1986). From this, we speculate that micro- 
organisms need more nitrogen to balance the salinity stress in high salinity marshes. This is supported by the elevated microbial storage of $\mathrm{N}$. The higher recorded respiration per cell $\left(\mathrm{Q}_{\mathrm{CO} 2}\right)$ for the high salinity sites reflects, as discussed above, a higher cellular energy demand under salinity stress.

In conclusion, we found that nutrient in microbial biomass and $\mathrm{C}, \mathrm{N}$ and $\mathrm{P}$ turnover rates in Belizian wetland sediments were impacted by $\mathrm{P}$ addition and the accompanied increase in macrophyte production. Microbial activities were affected differently based somewhat on plant species stoichiometry. Perhaps more important than litter stoichiometry are the distinctly different nutrient usage strategies employed by Eleocharis and Typha and the effect this has on microbial nutrient availability. As a result, Eleocharis supported a more balanced system with microorganisms kept in fast turnover, while microorganisms in Typha plots were more dependent on $\mathrm{P}$ addition. As hypothesized, microbial activities were salinity dependant. Salinity reduced the overall rates of microbial processes, weakened the positive effect of both $\mathrm{P}$ addition and plant species on microbial activities, and enhanced the amount of $\mathrm{N}$ stored in microbial cells.

Acknowledgements We would like to thank Ireneo Briceno, Russell King and Peter Macek for their assistance in the field, Emily Carlson, Karolina Tahovská, Eva Kaštovská, Daniel Vaněk and Tomáš Picek for laboratory assistance and to the journal editor and anonymous reviewers for their helpful comments and suggestions. This research was supported by these grants: NSF \# 0089211 to E. R.; ME 912, and MSM \# 6007665801 to H. $\breve{S}$.

Open Access This article is distributed under the terms of the Creative Commons Attribution Noncommercial License which permits any noncommercial use, distribution, and reproduction in any medium, provided the original author(s) and source are credited.

\section{References}

Anderson TH, Domsch KH (1985) Determination of ecophysiological maintenance carbon requirements of soilmicroorganisms in a dormant state. Biol Fert Soils 1:8189

Anderson TH, Domsch KH (1989) Ratios of microbial biomass carbon to total organic carbon in arable soils. Soil Biol Biochem 21:471-479

Anderson TH, Domsch KH (1990) Application of ecophysiological quotients $\left(\mathrm{Q}_{\mathrm{CO} 2}\right.$ and $\left.\mathrm{Q}_{\mathrm{D}}\right)$ on microbial biomasses from soils of different cropping histories. Soil Biol Biochem 22:251-255
Bagwell CE, La Rocque JR, Smith GW et al (2002) Molecular diversity of diazotrophs in oligotrophic tropical seagrass bed communities. FEMS Microbiol Ecol 39:113-119

Balderston WL, Sherr B, Payne WJ (1976) Blockage by acetylene of nitrous oxide reduction in Pseudomonal perfectomsrinus. Appl Environ Microbiol 31:504-504

Bastviken SK, Eriksson PG, Premrov A, Tonderski K (2005) Potential denitrification in wetland sediments with different plant species detritus. Ecol Eng 25:183-190

Benner R, Newell SY, Maccubbin AE, Hodson RE (1984) Relative contributions of bacteria and fungi to rates of degradation of lignicellulosic detritus in salt-marsh sediments. Appl Environ Microbiol 48:36-40

Boschker HTS, de Brouwer JFF, Cappenberg TE (1999) The contribution of macrophyte-derived organic matter to microbial biomass in salt-marsh sediments: stable carbon isotope analysis of microbial biomarkers. Limnol Oceanogr 44:309-319

Bossio DA, Scow KM (1998) Impacts of carbon and flooding on soil microbial communities: phospholipid fatty acid profiles and substrate utilization patterns. Microb Ecol 35:265-278

Bridgham SD, Richardson CJ (1992) Mechanism controlling soil respiration $\left(\mathrm{CO}_{2}\right.$ and $\left.\mathrm{CH}_{4}\right)$ in southern peatlands. Soil Biol Biochem 24:1089-1099

Burke DJ, Hamerlynck EP, Hahn D (2002) Interactions among plant species and microorganisms in salt marsh sediments. Appl Environ Microbiol 68:1157-1164

Calderon FJ, Jackson LE, Scow KM, Rolston DE (2001) Shortterm dynamics of nitrogen, microbial activity, and phospholipid fatty acids after tillage. Soil Sci Soc Am J 65:118-126

Černá B, Rejmánková E, Snyder JM, Šantrůčková H (2009) Heterotrophic nitrogen fixation in oligotrophic tropical marshes: changes after phosphorus addition. Hydrobiologia 627:55-65

Childers DL, Doren RF, Jones R, Noe GB, Rugge M, Scinto LJ (2003) Decadal change in vegetation and soil phosphorus pattern across the Everglades landscape. J Environ Qual 32:344-362

Corstanje R, Reddy KR, Prenger JP, Newman S, Ogram AV (2007) Soil microbial eco-physiological response to nutrient enrichment in a sub-tropical wetland. Ecol Indicators 7:277-289

Créach V, Lucas F, Deleu C, Bertru G, Mariotti A (1999) Combination of biomolecular and stable isotope techniques to determine the origin of organic matter used by bacterial communities: application to sediment. J Microbiol Met 38:43-52

Csonka LN (1989) Physiological and genetic responses of bacteria to osmotic stress. Microbiol Rev 53:121-147

Cunha MA, Almeida MA, Alcantara F (2000) Pattes of ectoenzymatic and heterotrophic bacterial activities along a salinity gradient in a shallow tidal estuary. Mar Ecol Prog Ser 204:1-12

Davis SM (1991) Growth, decomposition, and nutrient retention of Cladium jamaicense Crantz and Typha domingensis pers in the Florida Everglades. Aquat Bot 40:203-224

DeBusk WF, Reddy KR (1998) Turnover of detrital organic carbon in a nutrient-impacted Everglades marsh. Soil Sci Soc Am J 62:1460-1468 
Drake HL, Aumen NG, Kuhner C, Wagner C, Grießhammer A, Schmittroth M (1996) Anaerobic microflora of Everglades sediments: effects of nutrients on population profiles and activities. Appl Environ Microbiol 62:486-493

Ettema CH, Lowrance R, Coleman DC (1999) Riparian soil response to surface nitrogen input: temporal changes in denitrification, labile and microbial $\mathrm{C}$ and $\mathrm{N}$ pools, and bacterial and fungal respiration. Soil Biol Biochem 31:1609-1624

Francoeur SN, Schaecher M, Neely RK, Kuehn KA (2006) Periphytic photosynthetic stimulation of extracellular enzyme activity in aquatic microbial communities associated with decaying typha litter. Microb Ecol 52:662-669

Frostegård A, Tunlid A, Bååth E (1993) Phospholipids fatty acid composition, biomass and activity of microbial communities from two soil types exposed to different heavy metals. Soil Biol Biochem 25:723-730

Fulco AJ, Bloch K (1964) Cofactor requirments for formation of delta9-unsaturated fatty acids in Mycobacterium phlei. J Biol Chem 239:993-998

Galinski EA, Trüper HG (1994) Microbial behavior in salt stressed ecosystems FEMS Microbiol Rev 15:95-108

Grime JP (2001) Plant strategies: vegetation processes and ecosystem properties. John Wiley \& Sons, Chichester

Haack SK, Garchow H, Odelson DA, Forney LJ, Klug MJ (1994) Accuracy, reproducibility and interpretation of fatty acids methyl-ester profiles of model bacterial communities. Appl Environ Microbiol 60:2483-2493

Hardy RWF, Holsten RD, Jackson EK, Burns RC (1968) Acetylene-ethylene assay for $\mathrm{N}_{2}$ fixation-laboratory and field evaluation. Plant Physiol 43:1185-1191

Imhoff JF (1986) Osmoregulation and compatible solutes in Eubacteria. FEMS Microbiol Rev 39:57-66

Johnson S, Rejmánková E (2005) Impacts of land use on nutrient distribution and vegetation composition of freshwater wetlands in Northern Belize. Wetlands 25:89-100

Kaneda T (1991) Iso- and anteiso-fatty acids in bacteria, biosynthesis, function, and taxonomic significance. Microbiol Rev 55:288-302

Kieft TL, Wilch E, Oconnor K, Ringelberg DB, White DC (1997) Survival and phospholipid fatty acid profiles of surface and subsurface bacteria in natural sediment microcosms. Appl Environ Microbiol 63:531-1542

Kozub DD, Liehr SK (1999) Assessing denitrification rate limiting factors in a constructed wetland receiving landfill leachate. Water Sci Technol 40:75-82

Macek P, Rejmánková E (2007) Response of emergent macrophytes to experimental nutrient and salinity additions. Funct Ecol 21:478-488

McNamara AE, Hill WR (2000) UV-B irradiance gradient affects photosynthesis and pigments but not food quality of periphyton. Freshwater Biol 43:649-662

Moriarty DJW, Pollard PC (1981) DNA synthesis as a measure of bacterial productivity in seagrass sediments. Mar Ecol Prog Ser 5:151-156

Nielsen LP (1990) Denitrification and photosynthesis in stream sediment studied with microsensor and wholecore techniques. Limnol Oceanogr 35:1135-1144

Olsen SR, Sommers LE (1982) Phosphorus. In: Page AL (ed) Methods of soil analysis, part 2-chemical and microbi- ological properties. American Society of Agronomy, Soil Science Society of America, Madison, pp 403-430

Owens LB, Nelson DW, Sommers LE (1977) Determination of inorganic phosphorus in oxalate extracts of soils. Soil Sci Soc Am J 41:148-149

Pomeroy LR, Wiegert RG (1981) Ecology of a salt marsh. Springer.

Ravit B, Ehenfeld JG, Haggblom MM (2006) Effects of vegetation on root-associated microbial communities: a comparison of disturbed versus undisturbed estuarine sediments. Soil Biol Biochem 38:2359-2371

Reddy KR, White JR, Wright A, Chua T (1999) Influence of phosphorus loading on microbial processes in the soil and water column of wetlands. In: Reddy KR, O'Connor GA, Schelske CL (eds) Phosphorus biogeochemistry in subtropical ecosystems. Lewis Publishers, Boca Raton, pp 249-273

Rejmánková E (2001) Effect of experimental phosphorus enrichment on oligotrophic tropical marshes in Belize, Central America. Plant Soil 236:33-53

Rejmánková E (2005) Nutrient resorption in wetland macrophytes: comparison across several regions of different nutrient status. New Phytologists 167:471-482

Rejmánková E, Komárková J (2000) A function of cyanobacterial mats in phosphorus-limited tropical wetlands. Hydrobiologia 431:135-153

Rejmánková E, Macek P (2008) Response of root and sediment phosphatase activity to increased nutrients and salinity. Biochemistry 90:159-169

Rejmánková E, Post R (1996) Methane production in sulfate rich and sulfate poor wetland sediments. Biogeochemistry 34:57-70

Rejmánková E, Komárek J, Komárková J (2004) Cyanobacteriaa neglected component of biodiversity, patterns of species diversity in inland marshes of northern Belize (Central America). Diversity Distributions 10:189-199

Rejmánková E, Macek P, Kimberly Epps K (2008) Wetland ecosystem changes after three years of phosphorus addition. Wetlands 28:914-927

Robertson AI, Dixon P (1993) Separating live and dead fine roots using colloidal silica - an example from mangrove forests. Plant Soil 157:151-154

Šantrůčková H, Picek T, Šimek M et al (2001) Decomposition processes in soil of a healthy and a declining Phragmites australis stand. Aquat Bot 69:217-234

Semenov AM, van Bruggen AHC, Zelenev VV (1999) Moving waves of bacterial populations and total organic carbon along roots of wheats. Microbiol Ecol 37:116-128

Steingrobe B, Schmid H, Claassen N (2000) The use of the ingrowth core method for measuring root production of arable crops-influence of soil conditions inside the ingrowth core on root growth. J Plant Nutr Soil ScZeitschrift Fur Pflanzenernahrung Und Bodenkunde 163:617-622

Ste-Marie C, Paré D (1999) Soil, pH and N availability effects on net nitrification in the forest floors of a range of boreal forest stands. Soil Biol Biochem 31:1579-1589

Vance ED, Brookes PC, Jenkinson DS (1987) Microbial biomass measurements in forest soils - the use of the chloroform fumigation incubation method in strongly acid soils. Soil Biol Biochem 19:697-702 
Ward DM, Winfrey MR (1985) Interactions between methanogenic and sulfate-reducing bacteria in sediments. Adv Aquat Microbiol 3:141-179

Weisner SEB, Miao SL (2004) Use of morphological variability in Cladium jamaicense and Typha domingensis to understand vegetation changes in an Everglades marsh. Aquat Bot 78:319-335

Welsh DT, Herbert RA (1999) Osmotically induced intracellular trehalose, but not glycine betaine accumulation promotes desiccation tolerance in Escherichia coli. FEMS Microbiol Let 174:57-63

Wolin JA, Mackeigan P (2005) Human influence past and present-relationship of nutrient and hydrologic condi- tions to urban wetland macrophyte distribution. Ohio J Sci 105(5):125-132

Wright AL, Reddy KR (2001) Heterotrophic microbial activity in northern Everglades wetland soils. Soil Sci Soc Am J 65:1856-1864

Zahran HH (1997) Diversity, adaptation and activity of the bacterial flora in saline environments. Biol Fert Soils 25: 211-223

Zelles L, Bai QY, Beck T, Beese F (1992) Signature fattyacids in phospholipids and lipopolysacharides as indicators of microbial biomass and community structure in agriculture soils. Soil Biol Biochem 24:317323 